\title{
EARLY NEOLITHIC POTTERY FROM CENTRAL ASIA TO DENMARK
}

(C) 2017

Andreev Konstantin Mikhailovich, candidate of historical sciences, associate professor of Domestic History and Archeology Department

Vybornov Alexander Alexeevich, doctor of historical sciences, professor, head of Domestic History and Archeology Department

Samara State University of Social Sciences and Education (Samara, Russian Federation)

Abstract. This paper focuses on the analysis of the Early Neolithic cultures pottery on the vast territory from the Aral Sea region in the east to Denmark in the west. The most stable typological and technological features of ancient pottery are singled out: profiled upper part of the vessels, pointed bottom, poor ornamentation, pit or dash patterns under the rim, the compositions are represented by intersecting lines like an oblique lattice. The vessels are made of silty clay mixed with chamotte. The fragments of the surfaces are smoothed with a soft object. This set of features can be traced for the pottery of cultures in the Aral Sea region, forest-steppe part of the Volga region (Povolzhye), Don and Dnepr regions, up to Jutland. The radiocarbon dates for the Early Neolithic culture of the area of interest demonstrate their rather ancient age in the eastern part of the area $(6200 \mathrm{BC})$ and rather smooth transition to younger $(5900 \mathrm{BC})$ in the western zone. There is a combined chronointerval for the monuments of Elshanka and Ertebølle cultures. The reason for the eastern trend in the appearance of the earliest pottery to the west of the Aral Sea region could be climatic disturbances (aridization), while household components became the instrument for the early pottery appearance in the west.

Keywords: Early Neolithic; culture; pottery making techniques; pottery making tradition; Central Asia; foreststeppe part of Volga region (Povolzhye); Middle Don region; Dnepr region; absolute chronology; hunter-gatherer economy; fishing; Ertebølle.

УДК 902.6

Статья поступила в редакцию 12.05.2017

\section{О КУЛЬТУРНЫХ ГРАНИЦАХ ЕЛШАНСКОЙ КЕРАМИЧЕСКОЙ ТРАДИЦИИ}

(C) 2017

Ставицкий Владимир Вячеславович, доктор исторических наук, профессор кафедры всеобщей истории, историографии и археологии Пензенский государственный университет (2. Пенза, Российская Федерация)

Аннотация. Елшанский тип памятников был выделен в 1970-80-х годах после исследований в лесостепном Заволжье ряда памятников со слабоорнаментированной, шиподонной керамикой, имеющей профилированные венчики. Близких аналогов елшанской керамике в материалах сопредельных регионов найдено не было, зато был отмечен ряд параллелей в посуде памятников типа Струмель-Гастятин. Уже тогда было выделены два типа елшанской керамики: 1) остродонная и профилированная, 2) прямостенная и плоскодонная. В дальнейшем это привело к дрейфу понятия «елшанский тип керамики», поскольку выборочные аналоги двум типам елшанских форм стали находить на целом ряде ранненеолитических памятников от Приуралья до бассейна Дона. Между тем такие признаки, как форма сосудов, слабая орнаментированность стенок, относятся к разряду элементарных, и их конвергентное появление весьма вероятно. Доказательством преемственности может служить только передача комплекса сложных признаков, которые не фиксируются между материалами Елшанки-Струмеля-Гастятина-Эртебелле, но которые имеют место между керамикой Елшанки и ранненеолитическими материалами прибалтийской стоянки Звидзе.

Ключевые слова: елшанская культура; ранний неолит; лесостепное Заволжье; керамические традиции; культурный импульс; неолитические поселения; мотивы орнамента; социальные связи; поселение Звидзе; неолитизация; культуре эртебелле; нарвская культура; раннекерамические навыки; луговской тип керамики.

Елшанский тип памятников был выделен в 197080-х годах после исследований в лесостепном Заволжье ряда стоянок со слабоорнаментированной, шиподонной керамикой, имеющей профилированные Sвидные венчики. Близких аналогов елшанской керамике в материалах сопредельных регионов найдено не было, зато, с одной стороны, был отмечен ряд параллелей в материалах пещеры Джебел, с другой - в посуде памятников типа Струмель-Гастятин в Поднепровье, Дубичай в Литве, Северной Белоруссии и эртебелле в Дании. Наличие отмеченного сходства позволило Н.Л. Моргуновой поддержать ранее высказанную В.Н. Даниленко [1] точку зрения о распространении ранненеолитических керамических традиций, наряду с распространением навыков производящей экономики через территорию Средней Азии на запад [2]. Однако данное положение было подвергнуто критике И.Б. Васильевым и А.А. Вы- борновым, которые отметили недостаточную аргументированность данной концепции, объяснив определенное сходство указанных материалов близкими закономерностями появления первой керамики у населения сходного (присваивающего) культурнохозяйственного типа [3, с. 52]. По итогам накопления новых материалов А.А. Выборнов скорректировал свою точку зрения, связав указанное сходство с процессами распространения керамического производства в результате влияния хозяйственно-бытовых факторов [4, с. 226].

При выделении елшанской керамики И.Б. Васильевым и А.А. Выборновым было отмечено, что по форме сосудов она подразделяется на два типа: 1) остродонная с профилированными S-видными венчиками, 2) плоскодонная с прямостенными, отогонутыми вовнутрь или S-видными венчиками, примесью органики, ямочно-жемчужными вдавлениями 
под венчиком, использованием прочерченного орнамента. Причем первоначально происхождение керамики второго елшанского типа связывалось с контактами носителей первого типа с населением Ceверного Прикаспия [3, с. 24-25].

Необходимо отметить, что расширенное толкование характерного комплекса елшанских признаков в дальнейшем привело к дрейфу понятия «елшанский тип керамики», поскольку выборочные аналоги подобному набору признаков в скором времени были зафиксированы на целом ряде ранненеолитических памятников, расположенных от Приуралья до бассейна Дона. Между тем такие признаки, как форма днищ и венчиков, слабая орнаментированность стенок, использование простейших элементов орнамента, относятся к разряду элементарных, и их конвергентное появление весьма вероятно. Доказательством преемственности культур может служить только передача комплекса сложных признаков, которые далеко не всегда фиксируются между материалами, в той или иной степени соотносимые исследователями с памятниками елшанского типа.

Для того, чтобы достоверно определить, где имело место елшанское влияние, а где аналогии носят случайный характер, необходимо выявить признаки, которые являются специфическими для елшанских древностей и которые не характерны для сопредельных культур раннего неолита. Обычно данный набор признаков выделяют по материалам эпонимного памятника. К сожалению, на Старо-Елшанской стоянке полного набора подобных признаков нет, возможно потому, что коллекция керамика с памятника довольно ограниченна. На наш взгляд, можно выделить 5 признаков, которые являются специфическими для елшанской керамики.

1) Сосуды с S-видными венчиками и шиподонными или остродонными днищами. Это два признака, но имеет значение только их сочетание, поскольку по отдельности эти признаки хотя и эпизодически, но в других культурах встречаются. Поэтому при наличии обоих признаков их удельный вес равен двум условным единицам, а при наличии одного только 0,5 .

2) Орнаментация точечными наколами. Среди сопредельных культур практически не известна. Вместе с тем, она эпизодически встречается в бугоднестровской культуре [5], на керамике романковского типа [6] и достаточно широко представлена на поселении Звидзе [7].

3) Косая прочерченная решетка. В культурах лесной зоны встречается крайне редко. Только эпизодически подобная композиция орнамента фиксируется на памятниках орловской [8] и каиршакской культур [9], хотя прочерченная орнаментация распространена в них очень широко. Известна подобная орнаментация в нарвской культуре [7] и культуре эртебелле [10].

4) «Висячие треугольники», выполненные из прочерченных линий или наколов. Подобные композиции встречаются в орловской и каиршакской культуpax, но не имеют там широкого распространения, в то время как на елшанских памятниках Заволжья они присутствуют в материалах большинства стоянок.

Остальные элементы либо встречаются в единичных случаях на елшанской керамике, либо не являются специфическими. При этом все названные признаки, в основном, характерны для 1-го типа елшанской керамики. Следует отметить, что именно на эти признаки опирались К.М. Андреев, И.Н. Васильева и
А.А. Выборнов при доказательстве возможной преемственности керамических традиций между елшанскими памятниками и культурой эртебелле [4].

Частота встречаемости перечисленных признаков на елшанских памятниках, которые представлены достаточно информативными коллекциями керамики, приведена в табл. 1. Кроме собственно елшанских стоянок в ней учтены также памятники, которые, по мнению К.М. Андреева [11], так или иначе связаны с елшанской культурой.

Таблица 1 - Специфические признаки елшанской керамики

\begin{tabular}{|l|c|c|c|c|c|c|}
\hline Елшанские памятники & 1 & 2 & 3 & 4 & 5 & 6 \\
\hline Ильинка & + & + & + & + & - & 4 \\
\hline Б. Раковка II & + & - & - & + & + & 3 \\
\hline Чекалино IV & + & + & + & - & + & 4 \\
\hline К. Городок & + & + & - & - & - & 2 \\
\hline Н. Орлянка II & + & + & + & + & + & 5 \\
\hline Лебяжинка IV & + & + & - & + & + & 4 \\
\hline Ст. Елшанка II & + & + & + & - & - & 3 \\
\hline Усть-Ташелка & + & - & + & - & + & 2,5 \\
\hline Елшанка ХI & + & - & + & $?$ & - & 2 \\
\hline Вьюново I & + & + & - & - & - & 2 \\
\hline Утюж I & + & + & - & - & - & 2 \\
\hline Ивановка & + & + & - & + & - & 3 \\
\hline Лебяжье I & - & - & - & + & - & 1 \\
\hline Луговое III & + & - & - & $?$ & - & 0,5 \\
\hline Озименки II & + & + & + & + & - & 4 \\
\hline Имерка VII & + & + & + & - & - & 3 \\
\hline Ковыляй I & + & + & - & - & - & 2 \\
\hline Шапкино VI & + & + & + & - & - & 3 \\
\hline Плаутино I & + & - & - & - & - & 0,5 \\
\hline Городок I & - & + & - & - & & 0,5 \\
\hline Щербинино ХV & + & - & - & - & - & 0,5 \\
\hline Устье Излегощи & + & - & - & - & - & 0,5 \\
\hline Ярлуковская Протока & + & - & - & - & - & 0,5 \\
\hline Липецкое озеро & - & - & - & - & - & 0 \\
\hline Черников Брод & - & - & - & - & - & 0 \\
\hline
\end{tabular}

Примечание. Условные обозначения колонок: 1 -S-видные венчики; 2 -шиподонные днища; 3 - точечные вдавления; 4 - косая решетка; 5 - висячие треугольники; 6 - число признаков.

В диссертации К.М. Андреева памятники с керамикой елшанского типа разделены на две группы: восточную и западную [11]. Дискуссионность подобного разделения уже отмечалась автором статьи [12; 13]. Если учитывать только специфические признаки, то складывается картина, согласно которой основные елшанские памятники, имеющие по 4-5 признаков, сконцентрированы в бассейне реки Сок, кроме того один памятник известен на р. Мокше (Озименки II). Памятники, имеющие по три признака, кроме Сока известны в бассейне р. Самары, а также есть по одному памятнику на р. Вад (Имерка VII) и Хопер (Шапкино VI) (рис. 1).

Таким образом, можно отметить, что в материалах стоянок Примокшанья и Прихоперья фиксируются аналоги на уровне преемственности комплекса сложных признаков. Причем данные материалы, в основном, соответствуют 1-му елшанскому типу керамики. Сосуды имеют острые днища, профилированные S-видные венчики, украшенные рядами точечных наколов или неорнаментированные. В еди- 
ничных случаях зафиксированы прочерченные композиции в виде типично елшанской косой решетки. Именно данное сочетание сложных признаков является культуроопределяющим для елшанского типа памятников, поскольку черты присущие для 2-го елшанского (луговского) типа керамики не образуют комбинации сложных признаков, преемственность которых может быть уверенно установлена в ранненеолитических материалах других регионов. Данное утверждение относится к материалам стоянок: Устье Излегощи 2 (Подонье), Старое Щербинино 15 (Верхнее Поволжье), Городок 1 (Поочье), аналоги которым в елшанских древностях имеют выборочный ха- рактер. Из всего комплекса специфических признаков для них характерны только S-видные венчики. Определенное сходство данных материалов может быть связано с общим источником заимствования первоначальных традиций изготовления керамики, и все они, видимо, относятся к единому культурноисторическому горизонту ранненеолитических памятников лесостепной зоны. Наличие же ряда специфических елшанских признаков на стоянках Примокшанья и Прихоперья, видимо, следует расценивать в качестве кратковременных импульсов заволжского населения, которое разносили раннекерамические навыки.

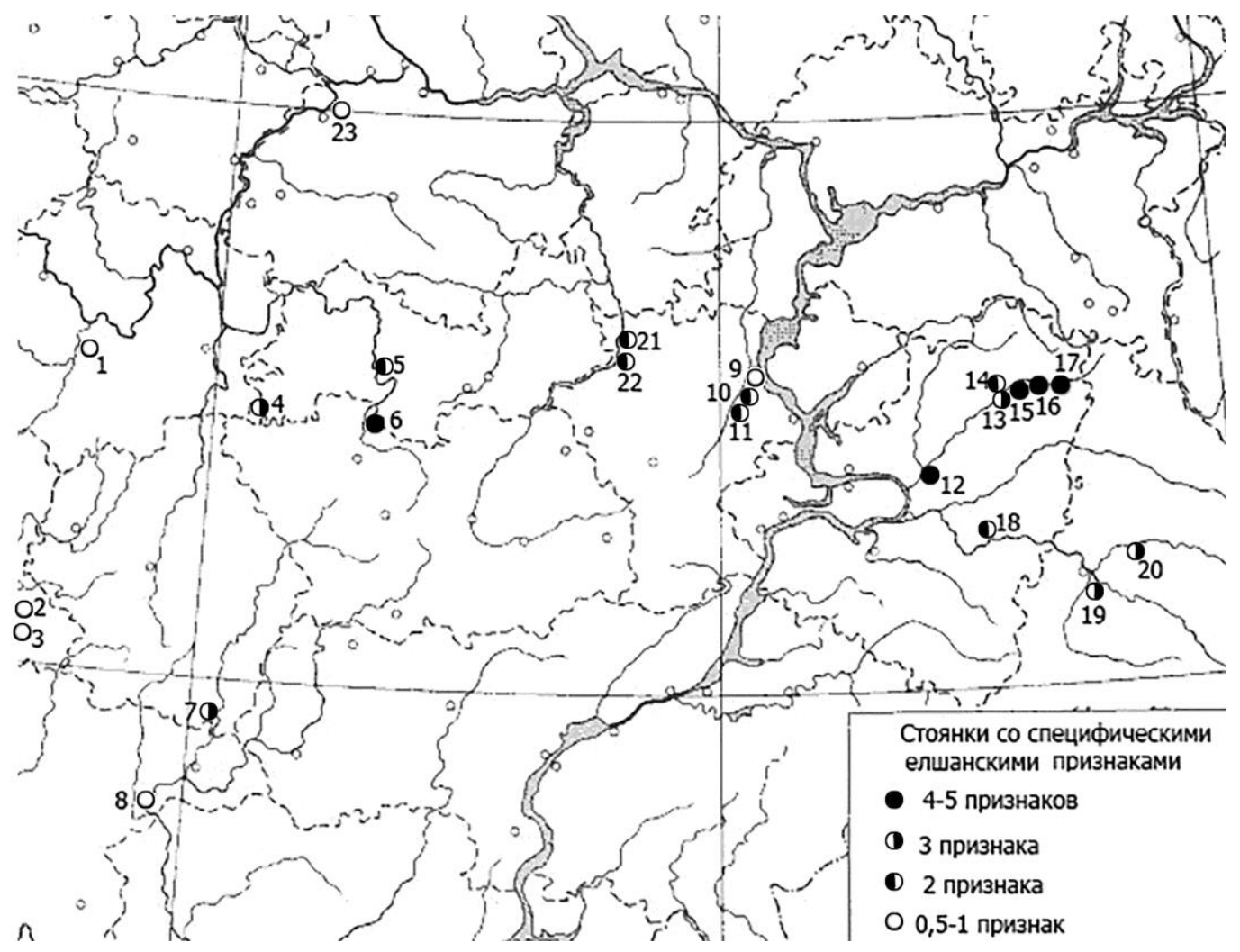

Рисунок 1 - Стоянки с елшанскими признаками.

1 - Городок I; 2- Ярлуковская протока (пункт 222); 3-Устье р. Излегощи; 4- Имерка VII; 5- Ковыляй I; 6- Озименки II; 7- Шапкино VI; 8- Плаутино I; 9 - Луговое III; 10- Усть-Ташелка (Елшанка X); 11 - Елшанка XI; 12 - Ильинка; 13 - Большая Раковка II; 14- Красный Городок; 15- Лебяжинка IV; 16 - Нижняя Орлянка II; 17- Чекалино IV; 18 - Виловатое; 19- Старая Елшанка II; 20 - Ивановка; 21 - Утюж I; 22 - Вьюново озеро I; 23 - Щербинино XV

В одной из работ В.И. Тимофеева [14] был поставлен вопрос о выделении особого елшанского раннекерамического очага, с которым было связано дальнейшее распространение керамических традиций как на сопредельные, так и на отдаленные территории. Данные выводы в значительной мере были основаны на хронологическом приоритете елшанских памятников, по которым были получены самые ранние даты. Однако в дальнейшем достоверность ряда дат была поставлена под сомнение, кроме того, не менее древние даты были получены для памятников Нижнего Поволжья и Дона. В недавней статье А.А. Выборновым и И.Н. Васильевой [15] был поставлен вопрос об одновременном зарождении керамических традиций в трех региональных очагах: средневолжском, нижневолжском и нижнедонском, что в принципе лишает елшанские древности монопольного приоритета в вопросах распространения керамических традиций на территорию лесной зоны.

Однако не следует сбрасывать со счетов того факта, что специфический комплекс ранненеолити102 ческих признаков 1-го елшанского типа наиболее раннюю хронологию имеет на территории Самарского Заволжья. Самарским датам уступает даже наиболее ранняя керамика сходного облика с территории Анатолии [16; 17]. Долгое время подобные хронологические ножницы вызывали недоумение, поскольку считалось, что изобретение керамики тесно связано с распространением производящего хозяйства, потребностями которого и объяснялось появление глиняной посуды. Однако исследования последних десятилетий дальневосточных памятников каменного века показали, что керамика появляется здесь в среде охотников и рыболовов, намного раньше, чем производящее хозяйство [18].

Поэтому вполне допустима вероятность того, что елшанская керамическая традиция могла зародиться на территории Самарского Заволжья, а не была привнесена откуда-то извне. В пользу высказанного предположения свидетельствуют данные ДНК-анализа двух погребений, зафиксированных на стоянке Лебяжинка IV и Чекалино IV, которые их исследова- 
тели относят к раннему неолиту. На стоянке Чекалино IV в небольшом материковом углублении исследовано безынвентарное погребение, сильно скорченное, расположенное на левом боку, которое А.Е. Мамонов датировал временем формирования елшанского культурного слоя $[19$, с. 6-7]. На стоянке Лебяжинка IV в заполнении юго-западной части жилищного котлована обнаружено вытянутое на спине погребение [20, с. 224], которое К.М. Андреев склонен относить к развитому неолиту $[11$, с. 86$]$. Несмотря на существенные отличия в погребальном обряде умерших и строении черепа [21], оба индивида близки друг другу генетически. Чекалинское погребение относится к галогруппе U5a, а лебяжинское к галогруппе U5a1 [22]. Следует отметить, что подобный набор генов весьма характерен для мезолитического населения Европы и практически не имеет ничего общего с неолитическим населением Передней Азии [23], в керамических традициях которого присутствуют отдельные «елшанские» признаки. В связи с чем возникают вопросы: всегда ли повторяемость достаточно сложных признаков в материалах отдаленных друг от друга памятников следует считать проявлением контактов неолитического населения? Являются ли они результатом высокой мобильности населения в данную археологическую эпоху?

Особенно интересным в данном плане является ряд близких параллелей между елшанской керами- кой и посудой прибалтийского поселения Звидзе [7]. Сходство между ними прослеживается в форме остродонных сосудов с S-видными венчиками, в использовании точечных наколов и прочерченных линий, в ряде аналогичных композиций орнамента, среди которых косая прочерченная решетка, сочетание горизонтальных и наклонных рядов наколов точечной формы (рис. 2). При этом керамика Звидзе изготовлена с использованием раковинной примеси, что для елшанской посуды не характерно. По мнению керамистов, в определении вопросов преемственности культурных традиций технологические параметры изготовления керамики играют более важную роль, нежели форма и орнаментация сосудов. Однако, судя по этнографическим данным, именно орнамент является одним из этнокультурных маркеров этноса, поскольку орнаментальные композиции всегда воспроизводятся сознательно в рамках определенных традиций. В то время как на изменение технологии производства могут оказывать влияние процессы адаптации к новой сырьевой базе, сопряженные с миграциями населения. К изменению способов изготовления керамики может привести и открытие полезных свойств нового материала, дающего определенные преимущества в сравнении с прежним сырьем.

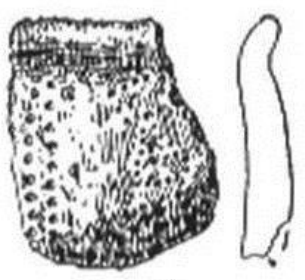

1

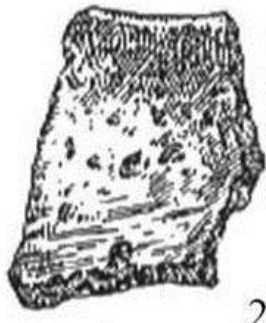

2

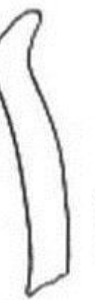

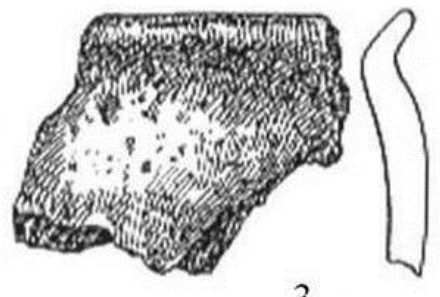

3

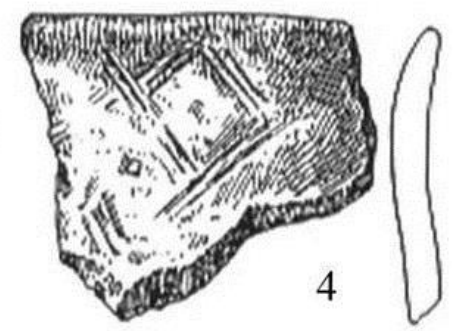

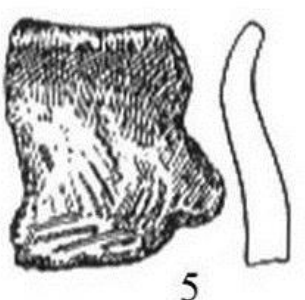

5

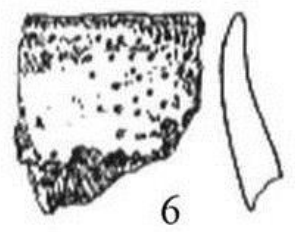

6

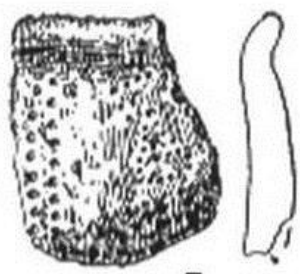

7

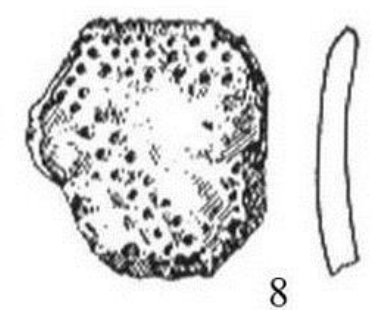

8

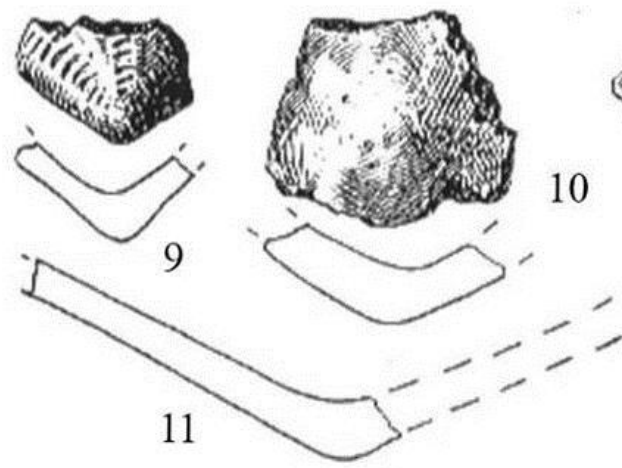

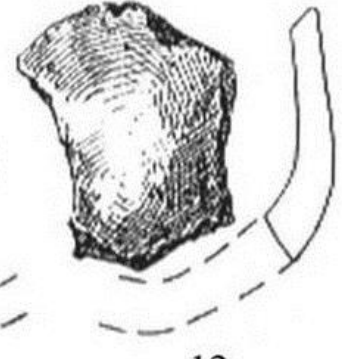

12

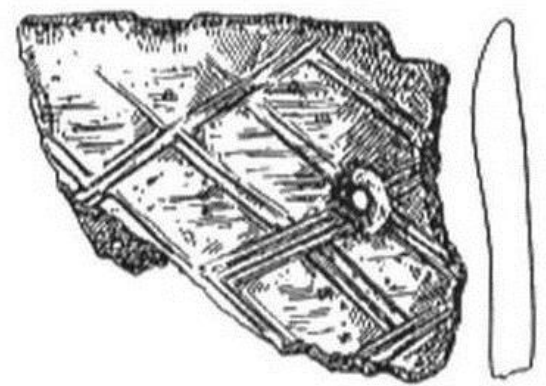

13

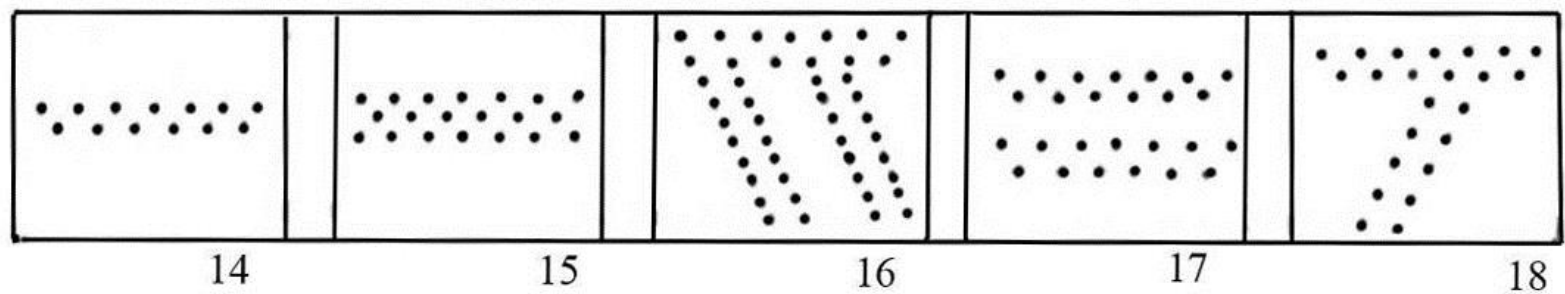

Рисунок 2 - Керамика с елшанскими признаками поселения Звидзе (по [7]) 


\section{СПИСОК ЛИТЕРАТУРЫ:}

1. Даниленко В.Н. Неолит Украины. Киев: Изд-во «Наукова Думка», 1969. 260 с.

2. Моргунова Н.Л. Эпоха неолита и энеолита в лесостепной зоне Волго-Уральского междуречья: автореф. дис. ... канд. ист. наук. М., 1984. 21 с.

3. Васильев И.Б., Выборнов А.А. Неолит Поволжья. Степь и Лесостепь: учеб. пособие к спецкурсу. Куйбышев: КГПИ, 1988. 112 с.

4. Андреев К.М., Васильева И.Н., Выборнов А.А. Ранненеолитическая керамика: от елшанской до Эртебелле // Культурные процессы в Циркумбалтийском пространстве в раннем и среднем голоцене: доклады междунар. науч. конф., посв. 70-летию со дня рожд. В.И. Тимофеева, 26-28 апреля 2017 г. / отв. ред. Д.В. Герасимов СПб.: Издательство «Лема», 2017. С. 224-228.

5. Котова Н.С. Неолитизация Украины. Луганск: Шлях, 2002. 268 с.

6. Телегин Д.Я. Неолитическая керамика романковского типа в Киевском Поднепровье // Российская археология. 1995. № 1. С. 110-120.

7. Лозе И. Поселения каменного века Лубанской низины: мезолит ранний и средний неолит. Рига, 1988. $205 \mathrm{c}$.

8. Юдин А.И. Варфоломеевская стоянка и неолит степного. Саратов: Изд-во Саратовского университета, 2004. $200 \mathrm{c}$.

9. Васильев И.Б., Выборнов А.А., Козин Е.В. Исследование неолитической стоянки Каиршак III // Неолит и энеолит Северного Прикаспия. Куйбышев: КГПИ, 1989. С. 18-45.

10. Andersen S. Kitchen middens and the early pottery of Denmark // Early Pottery in the Baltic Dating. Origin and Social Context. Frankfurt, 2011. P. 193-216.

11. Андреев К.М. Ранний неолит лесостепного Поволжья: дис. ... канд. ист. наук. Самара, 2015. $282 \mathrm{c}$.

12. Ставицкий В.В. К вопросу о выделении локальных вариантов елшанской культуры // Самарский научный вестник. 2016. № 4 (17). С. 74-77.
13. Ставицкий В.В. Дискуссионные вопросы изучения ранненеолитических памятников Среднего Поволжья // Международный научно-исследовательский журнал. 2017. № 5-1 (59). С. 87-89.

14. Тимофеев В.И. Некоторые проблемы неолитизации Восточной Европы // Тверской археологический сборник. Вып. 5. Тверь: Триада, 2002. С. 209214.

15. Васильева И.Н., Выборнов А.А. Время появления и динамика распространения неолитических керамических традиций в Поволжье // Поволжская Археология. 2016. № 3 (17). С. 104-123.

16. Ставицкий В.В. К вопросу о взаимодействии неолитического населения степной и лесостепной зоны в Поволжье // Самарский научный вестник. 2014. № 4 (9). С. 117-121.

17. Ставицкий В.В. Керамические традиции елшанской культуры: происхождение и хронология // Евразия в кайнозое. Стратиграфия, палеоэкология, культура. 2014. № 3. С. 136-141.

18. Кузьмин Я.В. Переход от палеолита к неолиту и возникновение керамики на Дальнем Востоке России: геоархеологический аспект // Археология, этнография и антропология Евразии. 2003. № 3. С. 16-25.

19. Мамонов А.Е. Елшанский комплекс стоянки Чекалино IV // Древние культуры лесостепного Поволжья. Самара: СГПУ, 1995. С. 3-25.

20. Овчинникова Н.В. Неолитическое жилище на поселении Лебяжинка IV в лесостепном Заволжье // Тверской археологический сборник. Вып. 7. Тверь: Триада, 2009. С. 220-229.

21. Хохлов А.А., Яблонский Л.Т. Палеоантропология Волго-Уральского региона эпохи неолитаэнеолита // История Самарского Поволжья с древнейших времен до наших дней Каменный век. Самара: Изд-во СНЦ РАН, 2000. С. 278-307.

22. Mesolithic Western Eurasian DNA [El. resourse] // Ancestral Journeys. - http://ancestraljourneys.org/ mesolithicdna.shtml.

23. DNA from the Near Eastern Neolithic [El. resourse] // Ancestral Journeys. - http://ancestraljourneys. org/wasianneolithicdna.shtml.

\title{
CULTURAL BORDERS OF ELSHANSKAYA CERAMIC TRADITION
}

(C) 2017

\author{
Stavitsky Vladimir Vyacheslavovish, doctor of historical sciences, \\ professor of General History, Historiography and Archeology Department \\ Penza State University (Penza, Russian Federation)
}

Abstract. Elshansky type of settlements was distinguished in the 1970s and 80s years after researches of a number
of the settlements with weakly ornamented ceramics with sharp bottom that have profiled brims in the forest-steppe
of Zavolzh'e. Close analogues to elshansky type of ceramics in the materials of the next regions has not been found,
but there were some parallels in the utensil of settlements of Strumel-Gastyatin type. It was already highlighted two
types of elshanskaya ceramics: 1) with sharp bottom and profiled, 2) with straight walls and flat-bottomed. Later this
lead to change the concept of «elshansky type of ceramics». Because the choosing analogues to two types of elshan-
skaya ceramics began to find on a number of early Neolithic settlements from the Urals to the basin of the river Don.
Meanwhile, such features as the shape of the vessels, weakly ornamented walls, belong to the category of the ele-
mentary and their convergent appearance is very likely. Only the transfer of the set of complex signs which are not
recorded between materials of elshanka-Strumel-Gastyatin-Artibelle could serve the argument of the succession, but
which take place between the ceramics Yelshanka and materials of the Baltic settlement Swidze.
Keywords: Elshanskaya culture; early Neolithic; steppe Trans-Volga; local variant; ceramic tradition; cultural
momentum; Neolithic settlements; ornamental motifs; settlement of Zvidze; Neolithization; Ertobelle culture; Narva
culture; Early ceramic skills; Lugovoe type of ceramics. 